\title{
IMPLEMENTATION OF WATER SUPPLY SUPERVISION IN CLASS 1 PORT HEALTH OFFICE IN JUANDA AIRPORT WORKING AREA, SURABAYA
}

\author{
Rizky Nugrahanik ${ }^{1}$, Bangun Cahyo Utomo \\ ${ }^{1}$ Departement of Enviromental Health \\ Faculty of Public Health, Airlangga University, Surabaya, Indonesia \\ ${ }^{2}$ Port Health Office Class 1 Surabaya Juanda Airport Work Area, Surabaya, Indonesia \\ Correspondence Adress: Rizky Nugrahanik \\ E-mail:Rizkynugrahanik@gmail.com
}

\begin{abstract}
The provision of clean water in the Class 1 Surabaya Port Health Office is supervised in accordance with the existing regulations to identify sources that could potentially cause pollution and prevent the occurrence of illness caused by unstandardized water quality and unsafe water supply. This study aimed to describe the implementation of clean water supply supervision in the Class 1 Surabaya Port Health Office in the Juanda Airport working area, Surabaya. This was an observational study which analysis was descriptive in nature. The clean water was tested for physical, chemical, and microbiological parameters, and the results showed that the water quality was in accordance with the Regulation of the Indonesian Ministry of Health No. 416 of 1990 about the Terms and Monitoring of Water Quality. However, the result from the simple chemical inspection test of the water showed that it did not fulfil health standards i.e., the residual chlorine score not equal to 0 (zero). It is suggested that more attention and supervision are conducted by water management authorities to ensure the standard residual chlorine level of 0 (zero). Additionally, expired reagents or reagents that have already changed color should not be used as it will affect the parameters tested.
\end{abstract}

Keywords: Quality of clean water, clean water supply facilities, water sampling process

\section{INTRODUCTION}

Water has an important role in the lives of all living things. For humans, water can be used for drinking, cooking, bathing and others. Many benefits can be obtained from water. It can maintain the health of the human body as it contains various important substances. If individuals always consume water regularly, it can help the metabolic process in their body run smoothly and avoid diseases to attack (Geost, 2018). Therefore, the water for consumption must be of good quality and meets health requirements. Based on the Regulation of the Indonesian Ministry of Health No. 416 of 1990 concerning the Requirements and Monitoring of Water Quality, water can be used for daily needs if its quality meets health requirements and has been boiled.

Until now, poor water quality has become a major problem as it has negative consequences for human health. Water is a medium that could also spread disease such as the pathogenic bacteria i.e.,
Escherichia coli (E. coli) (Zikra, 2018). Therefore, the availability of clean water must always be monitored in order to maintain its quality and ensure that it is safe enough for human consumption.

The emergence of some health problems in humans is also caused by poor sanitary conditions and unclean housing conditions, especially diarrheal diseases (Hatifah, 2019). Some diseases that are prevalent in Indonesia and can cause outbreaks are still difficult to control and can spread through water sources contaminated by E. coli (Dewanti, 2017).

The efforts that can be taken to determine the quality of water supply facilities include supervising or inspecting the quality of water sources or supply. The aim is to identify various sources that have the potential to cause pollution or contamination of water. The supervision is carried out in clean water supply facilities. Various physical, chemical, and bacteriological parameters must meet health requirements in order for the water to be safe for consumption (Natalia, 2013). 
The purpose of monitoring the quality of water is to prevent water downgrade and improve water quality.

The Port Health Office is the Technical Implementation Unit of the Ministry of Health which is under and reports to the Directorate General of Disease Control and Environmental Health. Based on the Regulation of the Indonesian Ministry of Health No. 2348/Menkes/Per/XI/2011 concerning Amendments to the Regulation of the Indonesian Ministry of Health No. 356/Menkes/Per/IV/2008 concerning the Organization and Administration of the Port Health Office, one of the duties of the Class 1 Surabaya Port Health Office is to supervise the provision of clean water carried out by the Environmental Risk Control Division. The monitoring of clean water significantly becomes one of the preventive efforts taken to minimize the occurrence of diseases caused by belowstandard water quality and facilities. Monitoring also prevents the emergence of waterborne diseases and cross contamination. The supervision of clean water supply must be carried out from the water source supplying to distribution to consumers.

Clean water supply supervision must be continuously monitored and carried out regularly in order to maintain the quality of clean water. A common waterborne disease is diarrhea as E. coli contaminates the water. Such incidents must be prevented by monitoring the provision of clean water and clean water supply facilities. Therefore, the implementation of supervision of clean water supply in the Class 1 Port Health Office in Surabaya must be carried out following the existing regulations to identify various pollution sources and prevent health problems in humans due to below-standard water quality. This study aimed to describe the implementation of clean water supply supervision in the Class 1 Port Health Office in Surabaya, Juanda Airport Working Area.

\section{METHOD}

This study was observational research with a descriptive research analysis. The population was the means of providing clean water by the Class 1 Surabaya Port Health Office in the Juanda Airport working area. The sample of the research was the provision of clean water in the aforementioned location.

The research was carried out in the Class I Surabaya Port Health Office in the working area of Juanda Airport, which is located at Jalan Raya Juanda Airport, Sedati Agung, Sedati, Sidoarjo Regency, East Java. The study was conducted from February to July 2019. The variables studied were location of clean water supply facilities, monitoring activities of clean water supply by the person in charge, and the quality of clean water including physical, chemical, and microbiological qualities.

This study used primary data and secondary data. The primary data included observations and inspections of clean water quality and supply facilities. Meanwhile, the secondary data were literature studies obtained from archives, profiles, monthly reports, annual reports, standard operating procedures (SOP), related laws and regulations, applicable field inspection forms, and other supporting documents.

The data collection instrument used was clean water quality and facility inspection forms adjusted to the Regulation of the Indonesian Ministry of Health in the Class 1 Surabaya Health Office.

The data obtained were analyzed descriptively based on the related theory and Regulation of the Indonesian Ministry of Health No. 416 of 1990 concerning the Requirements and Supervision of Water Quality and Decree of the Ministry of Health No. 431 of 2007 concerning Technical Guidelines for Environmental Health Risk Control at Ports/Airports/Cross-Border Posts in the 
Context of Health Quarantine. The research data have passed the eligibility test at the Faculty of Dental Medicine, Universitas Airlangga with the number: 347/HRECC.FODM/VI/2019.

\section{RESULTS}

The Class I Surabaya Port Health Office, has several working areas, which include Tanjung Perak Seaport, Gresik Seaport, Tuban Seaport, Kalianget Seaport, and Juanda Airport. Its main office is in the Juanda Airport.

The vision of the Class I Surabaya Port Health Office is to establish a port health office that is strong, professional and trustworthy in disease prevention and control at the entrance to Indonesia. The main tasks of the Class I Surabaya Port Health Office are to carry out prevention of entry and exit for disease and potential disease outbreaks, conduct epidemiological surveillance, quarantine, control environmental health impacts, provide health services, supervise drugs, food, cosmetics, medical devices and addictive materials (OMKABA), as well as observe new diseases and re-emerging diseases, bioterrorism, biological elements and chemical and radiation safeguards in the area of airports, seaports, and across national land borders. The Class- 1 Surabaya Port Health Office consists of the Administration Division, the Quarantine Control and Epidemiological Surveillance Division, the Environmental Risk Management Division, and the Health and Cross-Regional Efforts Division. Clean water monitoring activities are routinely carried out by the Environmental Risk Management Division.

Clean water supply supervision consists of checking the quality of clean water and monitoring the clean water supply facilities. It is routinely carried out once a month. The inspection of clean water quality includes examination of several parameters such as physical quality parameters (clarity, taste, smell, and color), simple chemical parameters $(\mathrm{pH}$ and residual chlorine), and microbiological parameters (E. coli and coliform/Total coliform bacteria). A reference for examining physical, chemical, and microbiological parameters is the Regulation of the Indonesian Ministry of Health No. 416 of 1990 concerning the Requirements and Monitoring of Water Quality.

Simple physical and chemical quality checks are regularly carried out by officers at Environmental Risk Management Division. Complete microbiological and chemical quality checks are carried out at the Surabaya Center for Health Laboratory or Surabaya BBTKL-PP. Water samples were taken at Reverse Osmosis PT. Angkasa Pura I (RO PAP), PAP Water Reservoir, PAP distribution water, water car, food processing place (TPM), and public places (TTU). The water quality inspection was carried out in the water car, and the water sample was extracted from the manhole in the water car. Meanwhile, for the water quality inspection at the food processing facility, samples were taken directly from the water gallon and domestic water. For the inspection of water quality in public places, water samples were taken from toilet water, sinks, and others.

Whereas, for monitoring on the location of clean water supply facilities, the quality was observed form the presence or absence of pipe leakage between the source and the reservoir, the condition of the release basin, reservoir manhole (whether or not there is chlorination in the reservoir tub), air holes (whether or not there are cracks in the reservoir tub), and the distribution pipes. Additionally, it was conducted to look into the conditions around the clean water supply facilities/facilities, namely puddles of liquid waste, pesticides, piles of garbage, and other types of waste around the reservoir. The supervision of clean water supply was carried out simultaneously with the inspection of clean water quality. 
PT. Angkasa Pura I (Persero) is a company that manages the JuandaSurabaya International Airport. The first location from which clean water samples were taken was at Reverse Osmosis (RO) PAP which consisted of 2 large reservoirs with a water capacity of $25 \mathrm{~m}^{3}$ or 25,000 liters each, the source of which was well water. The well water collected was given chlorine to remove bacteria, and it then flew into a filter to remove mud or dirt and manganese. After that, it flew to the CleanIn-place (CIP)-Tank which acted as a reservoir for filtered water. Next, it went directly to the membrane to be processed into clean water. Then, from the membrane, the water would flow to the Reservoir Tank (mixture of RO and PDAM) with a volume of more than 2,600 $\mathrm{m}^{3}$. The water would then be distributed to the Surabaya Juanda International Airport Branch Office.

Table 1. Results of Physical Quality Inspection of Clean Water at Class 1 Surabaya Port Health Office

\begin{tabular}{|c|c|c|c|c|}
\hline \multirow{2}{*}{ Location } & \multicolumn{4}{|c|}{ Physical Quality } \\
\hline & Clarity & Taste & Smell & Color \\
\hline Water Car 047 & Clear & Tasteless & No smell & Colorless \\
\hline Water Car 052 & Clear & & & \\
\hline & & Tasteless & No smell & Colorless \\
\hline Tandon & Clear & & & \\
\hline Lanudal & & Tasteless & No smell & Colorless \\
\hline $\begin{array}{l}\text { Water Car PT. } \\
\text { Sriwijaya }\end{array}$ & Clear & Tasteless & No smell & Colorless \\
\hline $\begin{array}{l}\text { Water Car PT. } \\
\text { CAS No. } 1007\end{array}$ & Clear & Tasteless & No smell & Colorless \\
\hline $\begin{array}{l}\text { Reverse } \\
\text { Osmosis PT. } \\
\text { PAP }\end{array}$ & Clear & Tasteless & No smell & Colorless \\
\hline $\begin{array}{l}\text { Tandon } \quad \text { PT. } \\
\text { PAP }\end{array}$ & Clear & Tasteless & No smell & Colorless \\
\hline $\begin{array}{l}\text { Distribution of } \\
\text { PT. PAP }\end{array}$ & Clear & Tasteless & No smell & Colorless \\
\hline $\begin{array}{l}\text { Isi ulang Kantin } \\
\text { Bunda }\end{array}$ & Clear & Tasteless & No smell & Colorless \\
\hline $\begin{array}{l}\text { Warung Cak } \\
\text { Mat }\end{array}$ & Clear & Tasteless & No smell & Colorless \\
\hline
\end{tabular}


Table 2. Results of Simple Chemical, Chemical, and Microbiological Quality Inspection of Clean Water, Class 1 Surabaya Port Health Office

\begin{tabular}{|c|c|c|c|c|c|}
\hline \multirow{2}{*}{ Location } & \multicolumn{2}{|c|}{$\begin{array}{c}\text { Simple } \\
\text { Chemistry } \\
\end{array}$} & \multirow{2}{*}{ Chemistry Inspection } & \multirow{2}{*}{ Microbiology } & \\
\hline & pH & $\begin{array}{l}\text { Residual } \\
\text { Chlorine }\end{array}$ & & & \\
\hline Water Car 047 & 7.6 & 0 & are not done & $\begin{array}{l}\text { Meet } \\
\text { requirements }\end{array}$ & the \\
\hline Water Car 052 & 7.6 & 0.2 & are not done & $\begin{array}{l}\text { Meet } \\
\text { requirements }\end{array}$ & the \\
\hline Tandon Lanudal & 7.8 & 0 & are not done & $\begin{array}{l}\text { Meet } \\
\text { requirements }\end{array}$ & the \\
\hline $\begin{array}{l}\text { Water Car PT. } \\
\text { Sriwijaya }\end{array}$ & 8 & 0 & are not done & $\begin{array}{l}\text { Meet } \\
\text { requirements }\end{array}$ & the \\
\hline $\begin{array}{l}\text { Water Car PT. } \\
\text { CAS No. } 1007\end{array}$ & 7.6 & 0.2 & are not done & $\begin{array}{l}\text { Meet } \\
\text { requirements }\end{array}$ & the \\
\hline $\begin{array}{l}\text { Reverse } \\
\text { Osmosis } \quad \text { PT. } \\
\text { PAP }\end{array}$ & 7.1 & 0.3 & Meet the requirements & $\begin{array}{l}\text { Meet } \\
\text { requirements }\end{array}$ & the \\
\hline Tandon PT. PAP & 7.1 & 0.3 & Meet the requirements & $\begin{array}{l}\text { Meet } \\
\text { requirements }\end{array}$ & the \\
\hline $\begin{array}{l}\text { Distribution of } \\
\text { PT. PAP }\end{array}$ & 7.8 & 0 & Meet the requirements & $\begin{array}{l}\text { Meet } \\
\text { requirements }\end{array}$ & the \\
\hline $\begin{array}{l}\text { Refill Mom's } \\
\text { Canteen }\end{array}$ & 7.1 & 0 & are not done & $\begin{array}{l}\text { Meet } \\
\text { requirements }\end{array}$ & the \\
\hline Stand's Cak Mat & 6.8 & 0 & are not done & $\begin{array}{l}\text { Meet } \\
\text { requirements }\end{array}$ & the \\
\hline
\end{tabular}

Based on Table 1, the results of the inspection of clean water on ten locations showed the water clarity, taste, smell, and color were in accordance with the Regulation of the Indonesian Ministry of Health No. 416 of 1990 concerning the Requirements and Supervision of Water Quality that should be clear, tasteless, odorless, and colorless.

Table 2 explains a simple chemical inspection of water quality by using a water test kit. It showed that the $\mathrm{pH}$ of the water examined on ten locations has met the health standards which $\mathrm{pH}$-values should be 6.5-9.0. While the examination for residual chlorine showed that on 6 locations the values were below 0.2 $\mathrm{mg} /$ liter or $0.2 \mathrm{ppm}$. There were also 2 locations with residual chlorine values of $0.2 \mathrm{ppm}$, and 2 remaining locations with the values of $0.3 \mathrm{ppm}$. Chemical examination was only carried out on 3 locations, namely RO PT. PAP, Tandon PT. PAP, and distribution area of PT. PAP. Based on the laboratory examination, the water quality met the requirements and was in accordance with the regulation.

The parameters examined were mandatory parameters that are directly and indirectly related to health. The directlyrelated health parameters were inorganic chemicals such as fluoride, cadmium, total chromium, nitrite (as NO3-), and nitrite (as NO2-) based on the laboratory test results 
on drinking water requirements. The indirectly-related health parameters were physical and chemical parameters. Physical parameters included temperature, odor, total dissolved solids (TDS), turbidity in water, taste, and color. Meanwhile, chemical parameters were $\mathrm{pH}$, iron, manganese, copper, zinc, ammonia, hardness, chloride, and sulfate. A physical examination of water included a complete chemical examination. Moreover, the microbiological examinations stated the water samples taken from 10 locations met health requirements and were in accordance with the standard.

\section{Sanitary conditions of piping system facilities by types}

Table 3. Results of Sanitation Inspection of Types of Piping System Facilities

\begin{tabular}{|c|c|c|}
\hline Locations & $\begin{array}{l}\text { Total } \\
\text { risk } \\
\text { score }\end{array}$ & $\begin{array}{l}\text { Sanitary } \\
\text { inspection } \\
\text { results } \\
\text { (Pollution risk } \\
\text { level) } \\
\end{array}$ \\
\hline $\begin{array}{l}\text { Reverse } \\
\text { Osmosis PT. } \\
\text { PAP }\end{array}$ & 0 & Low \\
\hline $\begin{array}{l}\text { Water } \\
\text { Reservoir } \\
\text { PT.PAP }\end{array}$ & 0 & Low \\
\hline $\begin{array}{l}\text { Tandon } \\
\text { lanudal PT. } \\
\text { Gapura } \\
\text { Angkasa }\end{array}$ & 0 & Low \\
\hline $\begin{array}{l}\text { Water car } \\
047\end{array}$ & 0 & Low \\
\hline $\begin{array}{l}\text { Water car } \\
052\end{array}$ & 0 & Low \\
\hline $\begin{array}{l}\text { Water car } \\
\text { PT. } \\
\text { Sriwijaya }\end{array}$ & 0 & Low \\
\hline $\begin{array}{l}\text { Water car } \\
\text { PT. CAS No. } \\
1007\end{array}$ & 0 & Low \\
\hline $\begin{array}{l}\text { Water car } \\
\text { PT. CAS No. } \\
1007\end{array}$ & 0 & Low \\
\hline
\end{tabular}

Table 3 exhibits the results of observations and assessments of clean water supply facilities on seven locations. The findings showed the total risk level score for the seven locations was 0 (zero). The total risk score ranges from $0-8$ and is divided into two criteria: low risk level (R) (score 0-4) and high risk level (T) (score 58 ). The smaller the score, the lower the risk level for water pollution.

\section{DISCUSSION}

\section{Inspection of the physical quality of clean water}

The physical quality of clean water was inspected by testing the clarity, taste, smell, and color. The samples were tested by using a water test kit. The results indicated that the quality of the water was in accordance with the standard.

\section{Clarity}

The quality of the water can be determined based on how cloudy the water is. The cloudier the water, the worse the quality. The clean water turbidity standard is 5 NTU. If the water is cloudy, this indicates that the TDS in the water is high. The cloudier the water, the higher the TDS value of the water. If the turbidity in the water is less than $5 \mathrm{NTU}$, the mineral content will be low. Biochemists also have explained that minerals play an important role in various bodily functions. In addition to bodily functions, minerals are used as raw material for enzyme performance. The results mentioned the quality of clean water on ten locations was good as it was clean and not cloudy.

\section{Taste, smell and color}

Turbid water indicates that the water is polluted. If the water is cloudy, it will smell and have a color. For example, water that is polluted by sewage from factories will smell bad, and the smell is often associated with the taste of water. Smell, taste, and color are parameters that are used to determine contamination in 
water (Caesar, 2017). Water that smells and tastes bad when used and consumed by humans can interfere with human health. The physical inspection of clean water showed the water was odorless and tasteless. There was no contamination in the water around the clean water supply facilities, and thus it could be used in everyday life.

\section{Simple chemical check of clean water quality}

Simple chemical tests included $\mathrm{pH}$ and residual chlorine testing. The technical guidelines adopted by Class 1 Surabaya Port Health Office were following the Decree of the Indonesian Ministry of Health No. 431/MENKES/SK/IV/2007 concerning the Technical Guidelines for Environmental Health Risk Control at Ports/Airports/Cross-Border Posts in the Context of Health Quarantine. It states that if the results are less than $0.2 \mathrm{ppm}$, then chemical status does not meet the health standards and indicates an imperfect chlorination process.

\section{Residual chlorine and $\mathrm{pH}$}

Water for human consumption must have a balanced $\mathrm{pH}$, which must not be too acidic or too alkaline because it can affect the consumer health. If water has a $\mathrm{pH}$ of below 6.5, it is considered too acidic. If the $\mathrm{pH}$ is above 8.5 , it is too alkaline for consumption. As corrosion can be caused by too acidic water, $\mathrm{pH}$ adjustment can help control the corrosion in the pipes of the water distribution system (Syahputra, 2012). This study found that the clean water available in the clean water supply facilities had a fulfilled $\mathrm{pH}$ level.

Moreover, there were several tests in which the residual chlorine level was 0 (zero). There were several possible reasons for the results. 1) The additional chlorine in the water evaporated due to exposure to sunlight even though the water system was closed. 2) Only a small amount of chlorine was added to the water. Therefore, when the inspection was conducted, the result was 0 (requirements: $250 \mathrm{mg} / \mathrm{l}$ ); 3). The use of unsuitable reagents, such as using expired reagents will affect the quality of the water being examined (SNI, 7828: 2012). 4) There was a means of providing clean water that is not given enough attention so that it can be used. Many facts affect water quality such as pipe leakage, distribution distance, and winding pipe shape which affects the chlorine content in the water (Afrianita, 2016). It is important to ensure that residual chlorine levels are up to standard. If the remaining chlorine in the water is 0 (zero), the water can be easily contaminated with bacteria. Conversely, if the remaining chlorine in the water is in excess, it can have an impact on human health, one of which is bladder cancer because chlorine is carcinogenic (Winati, 2014).

\section{Chemical and microbiological examination}

Based on the laboratory test results, the water samples met the clean water requirements. The results of the examination were in accordance with the standard. Humans can experience diarrhea if they have consumed water that has an excess of the E. coli. The bacteria can also spread to other organ or body systems and can infect the urinary tract to cause urinary tract infections (UTI). Moreover, the presence of coliform is closely related to the presence of feces in the water because coliform can come from feces. These types of bacteria are found everywhere, such as clean water, foodstuffs, and even in other materials used for human purposes. If coliform are found in clean water, foodstuffs and other ingredients, they have been contaminated by human feces. Therefore, the clean water standards require the amount of $E$. coli to be $0 / 100$ $\mathrm{ml}$ (Sunarti, 2016).

If the water tested has met the requirements, then the number of $E$. Coli/100 $\mathrm{ml}$ and total coliform/100 $\mathrm{ml}$ in water is 0 (zero). Based on the standard, 
the presence of E. Coli and coliform in the water must be 0 (zero) so as not to endanger human health. $E$. coli is a bacterium that is present in the human colon as a normal flora. However, this bacteria can cause primary infections in the human intestine and other body tissues outside the intestine.

Therefore, the quality of clean water must always be maintained, especially in regard to the contamination of E. Coli and coliform for their impacts to human health. Regular monitoring and testing are an example of the preventive measures from diseases due to water contaminated with $E$. coli. The laboratory test results demonstrated the clean water at Juanda Airport in Surabaya was of good and was suitable for the community consumption.

\section{Sanitary conditions of the piping system facilities}

The supervision in the piping system facilities was carried out together with the inspection of clean water quality. Overall, the clean water supply facilities did not obtain negative results as there was no pipe leakage between the source and reservoir. Therefore, the water was not contaminated by dirt or bacteria. Additionally, the release tub was properly closed, and the man-hole reservoir was tightly closed. The air holes were protected, and there were no cracks in the reservoir tub. Chlorination was also carried out in the reservoir tub to remove bacteria in the water, and there was no leakage in the distribution pipe. There was no puddle of liquid waste that could pollute the water, and there were no pesticides that could contaminate the water and endanger human health. Moreover, there were no piles of garbage nor other types of waste around the reservoir.

However, from the interview results, the main problem was chlorination process in the reservoir. In the interview, the officers mentioned the chlorination process was correct. However, when checking the remaining chlorine in the water, it turned out that the result was zero. While the residual chlorine in the water should be $0.2 \mathrm{ppm}$. The remaining chlorine in the water will prevent water from being contaminated with bacteria.

If all clean water supply sites have been inspected through laboratory tests and all physical, chemical, and bacteriological parameters have met the requirements, the Class 1 Surabaya Port Health Office will issue the Certificate of Water Quality Control, which is valid until the officer rechecks and provides the results of the inspection together with a new certificate. Based on the Decree of the Indonesian Ministry of Health No. 431/MENKES/SK/IV/2007 concerning Technical Guidelines for Environmental Health Risk Control at Ports/Airports/Cross-Border Posts in the Context of Health Quarantine, water sampling activities for chemical examinations should be conducted more frequently if there is a water-borne disease outbreak, pollution, and leakage/repair of the water distribution system.

\section{Compliance with the implementation of clean water supply supervision by the Class 1 Surabaya Port Health Office with Standard Operating Procedures (SOP)}

The clean water quality inspection (physical, chemical, simple chemical, and microbiological examinations) and the pollution level in the clean water supply facilities of Class 1 Surabaya Port Health Office met the standard requirements. The results of the inspection were also closely related to the preparation and implementation process of clean water supply supervision. From the observations and interviews, the implementation of clean water supply supervision was according to the Decree of the Indonesian Ministry of Health No. 431/MENKES/SK/IV/2007 concerning Technical Guidelines for Health Risk 
Control as Standard Operating Procedures (SOP).

There are 4 processes involved when supervising clean water supplies to check the quality of clean water and clean water supply facilities. In the preparation process, 1) a map/situation plan is created in advance to supervise the supply of clean water at the port/airport; 2) a schedule needs to be made for each activity undertaken, and thus the time and where water will be taken, when monitoring is carried out on the components of the water supply and distribution system, when and where guidance and direction are carried out, can be determined for inspection purposes; 3) tools and materials in the supervision will also need to be prepared. These include a water test kit, water inspection form, bacteriological sampling equipment (sample bottles, Bunsen burner, labels and sample flasks), tools for taking chemical samples (jerry cans and labels), and letters of assignment.

In the implementation process, the method used for taking water samples for bacteriological examination from a faucet or hydrant is as described below: a) Let the water flow for 2-3 minutes; b) Flame the faucet/hydrant first so that it is sterile (especially the mouth of the faucet/hydrant); c) Flow hot water through the faucet for about 2 minutes; d) Allow the water to fill the bottle until it reaches the neck of the bottle (at least $100 \mathrm{cc}$ ); e) Flush bottle mouth again and flame the lid before immediately closing the bottle (ensure that the lid is also not touched by bare hands); f) Add a label on the sample bottle which includes the number, date, time of collection, location of collection and the name of the water sample; g) The examination of bacteria is carried out in the laboratory and not by the officers themselves.

The method used for taking water samples for bacteriological examination on water boats or barges and cars or water tanks is as described below: a) Samples are taken through the main hole on the water boat or barge and car or water tank; b) Bottles, bottle caps, wrapping paper and other tools must be sterile; c) Hold the bottle using the left hand, then open the wrapping paper, open the bottle cap and the mouth of the bottle will be filled; d) Collect the water directly from the manhole; e) Flame the mouth and cap of the bottle; f) Add a label on the bottle that has been filled with water samples including the number, date, time of collection, location of collection and name of the person who collects the sample; g) Send the sample to the laboratory in within 24 hours of collection. If the delivery cannot be carried out immediately or if the laboratory is far away, the sample may be stored in a refrigerator or ice thermos to avoid the development of bacteria in the sample.

The method used for taking water samples for chemical examination of the water from a faucet or hydrant is as described below: a) Allow water from the tap to fill the jerry can up until five liters; b) Label the jerry can with information such as sample number, date, time of collection, location of collection and the name of the person who collects the sample.

The method used for taking water samples for chemical examination of the water from water boats or barges and cars or water tanks is as described below: a) Collect water samples through the main holes on the water boats or barges and cars or water tanks; b) Rinse the jerry cans three times before filling the jerry cans with water samples; c) Fill the jerry can with five liters of sample water; d) Label the jerry with information such as sample number, date, time of collection, location of collection and name of the person who collected the sample; e)Add a sodium thiosulfate preservative if the sample is sent to the laboratory more than 24 hours since its collection.

The results of bacteriological examinations of the water sample for residual chlorine should not be less than 
$0.2 \mathrm{mg} /$ liter or $0.2 \mathrm{ppm}$ (if using chlorine as a disinfectant). The residual chlorine in the water should be less than $0.2 \mathrm{mg} / \mathrm{liter}$ or $0.2 \mathrm{ppm}$. Then, the State in full must provide advice as well as a suggestion for corrective action.

The third process is supervision of the drinking water supply from source supplying to distribution to consumers. This includes supervising the conditions of the water facilities, maintenance of water facilities and repairs (if they do not meet the set standards), supervision and counseling on how to supply clean water, as well as hygiene and sanitary water handling practice.

The fourth process is implementation. The supervisor of clean water supply are civil servants at the Class 1 Surabaya Port Health Office who have a minimum education of Diploma 1 in Sanitation and/or has received training in sanitarian positions.

Overall, the implementation of clean water supervision at Class 1 Surabaya Port Health Office was in accordance with the SOP. The Class 1 Surabaya Port Health Office officers prepared the equipment, implemented set procedures, and supervised clean water supply facilities. However, there were some aspects that were not done by the officers because they were carried out by laboratory staff at BBTKL or BBLK Surabaya. The Class 1 Surabaya Port Health Office officers only took samples and sent them to the laboratory for examination.

The Class 1 Surabaya Port Health Office holds a significant role in supervising the provision of clean water to maintain its quality. Clean water monitoring is a preventive measure from water contamination. Moreover, when there are problems related to water such as water-borne disease, pollution, and leakage/repairs of the water distribution system, the Class 1 Surabaya Port Health Office will control and supervise the clean water supply.

\section{CONCLUSION}

The clean water quality inspection conducted at the Class 1 Surabaya Port Health Office discovered the physical, chemical, and microbiological statuses met the health requirements and were in accordance with the Regulation of the Indonesian Ministry of Health No. 416 of 1990 concerning the Requirements and Monitoring of Water Quality. Meanwhile, the simple chemical examination showed there was 0 (zero) chlorine residue which did not follow the standard. In terms of piping systems, the level of risk for water pollution was low. To minimize the occurrence of errors when adding chlorine to clean water, the Class 1 Surabaya Port Health Office should pay greater attention and supervise the chlorination of water conducted by the clean water supply manager at the airport to meet the standard residual chlorine level. Moreover, expired reagents or reagents which color has changed should not be used when performing a clean water inspection because it will affect the results of the parameter testing.

\section{REFERENCES}

Afrianita, R., Komala, P. S., dan Andriani, Y. (2016). OP-026 Kajian Kadar Sisa Klor Di Jaringan Distribusi Penyediaan Air Minum Rayon 8 Pdam Kota Padang. In Seminar Nasional Sains dan Teknologi Lingkungan II.

Caesar, D. L., dan Prasetyo, E. (2017). Analisis Kualitas Fisik Air Desa Cranggang Kecamatan Dawe Kabupaten Kudus. Jurnal Kesehatan Masyarakat (JKM) CENDEKIA UTAMA, 5(1).

Decree of the Minister of Health of the Republic of Indonesia. 2007. Keputusan Menteri Kesehatan Republik Indonesia Nomor 431/MENKES/SK/IV/2007 Tentang Pedoman Teknis Pengendalian Risiko Kesehatan Lingkungan di 
Pelabuhan/Bandara/Pos Lintas Batas dalam Rangka Karantina Kesehatan.

Dewanti, R. A., dan Sulistyorini, L. (2017). Analisis Kualitas Bakteriologis Air Minum Isi Ulang Di Kelurahan Sememi, Kecamatan Benowo. The Indonesian Journal of Public Health, 12(1), 39-50. https://doi.org/http://dx.doi.org/10.20 473/ijph.v12i1.2017.39-50

Geost, F. (2018). Apa itu Air? Pengertian, Fungsi, Sumber, dan Manfaatnya.

Hatifah, P., Anwar, A., dan Risva, R. (2019). Faktor-Faktor Yang Berhubungan Dengan Kualitas Bakteorologis E.Coli Sungai Karang Mumus Serta Gejala Diare Pada Balita Di Kelurahan Bandara Kecamatan Sungai Pinang Kota Samarinda. HIGIENE: Jurnal Kesehatan Lingkungan, 4(3), 159168. Universitas Islam Negeri Alauddin Makassar

Natalia, L., Bintari, S., dan Mustikaningtyas, D. (2013). Kajian Kualitas Bakteriologis Air Minum Isi Ulang Di Kabupaten Blora. Unnes Journal of Life Science, 2(2), 71-77.

Regulation of the Minister of Health. 1990. Peraturan Menteri Kesehatan Nomor : $\quad$ 416/MEN.KES/PER/IX/1990 Tentang Syarat-syarat Dan Pengawasan Kualitas Air.

Regulation of the Minister of Health. Peraturan Menteri Kesehatan Republik Indonesia Nomor 2348/Menkes/Per/Xi/2011 Tentang Perubahan Atas Peraturan Menteri Kesehatan Nomor 356/Menkes/Per/Iv/2008 Tentang Organisasi Dan Tata Kerja Kantor Kesehatan Pelabuhan.

SNI. 7828:2012. Kualitas air Pengambilan contoh - Bagian 5:
Pengambilan sontoh air minum dari instalasi pengolahan air dan sistem jaringan distribusi perpipaan (ISO 5667-5:2006, MOD).

Sunarti, R. N. (2016). Uji Kualitas Air Mium Isi Ulang di Sekitar Kampus UIN Raden Fatah Palembang. Bioilmi: Jurnal Pendidikan, 2(1).

Syahputra, B. (2012). Prosiding SNST ke-3 Tahun 2012 Fakultas Teknik Universitas Wahid Hasyim Semarang ANALISA SISA CHLOR PADA JARINGAN DISTRIBUSI AIR MINUM PDAM KOTA SEMARANG. $1-5$.

Winati, L. (2014). Alasan kenapa kadar klor tidak boleh berlebih di air.

Zikra, W., Amir, A., dan Putra, A. E. (2018). Identifikasi Bakteri Escherichia coli (E.coli) pada Air Minum di Rumah Makan dan Cafe di Kelurahan Jati serta Jati Baru Kota Padang. Jurnal Kesehatan Andalas, 7(2), 212-216. 